\title{
Article
}

\section{Doing my homework: sources of confidence for primary educators teaching science}

\author{
Canovan, Cherry
}

Available at http://clok.uclan.ac.uk/37631/

Canovan, Cherry ORCID: 0000-0002-9751-5646 (2021) Doing my homework: sources of confidence for primary educators teaching science. Academia Letters.

It is advisable to refer to the publisher's version if you intend to cite from the work. https://doi.org/10.20935/AL675.

For more information about UCLan's research in this area go to http://www.uclan.ac.uk/researchgroups/ and search for < name of research Group>.

For information about Research generally at UCLan please go to http://www.uclan.ac.uk/research/

All outputs in CLoK are protected by Intellectual Property Rights law, including Copyright law. Copyright, IPR and Moral Rights for the works on this site are retained by the individual authors and/or other copyright owners. Terms and conditions for use of this material are defined in the policies page.

\section{CLoK}

Central Lancashire online Knowledge www.clok.uclan.ac.uk

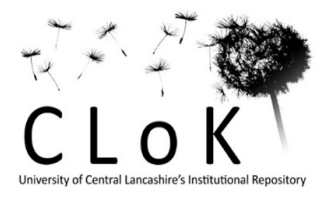




\title{
ACADEMIA $\mid$ Letters
}

\section{Doing my homework: sources of confidence for primary educators teaching science}

\author{
Cherry Canovan
}

\section{Introduction}

Primary teachers' confidence and expertise in teaching science has been a source of concern and debate in the UK for decades (eg Harlen \& Holroyd, 1997; Khwaja, 2002; Murphy et al., 2007; Ofsted, 2013; Wellcome, 2014).

A recent contribution to our understanding of this issue comes from a report for the Wellcome Trust by Leonardi (Wellcome Trust, 2017) which analysed the findings of around 900 computer-assisted interviews with primary school science leads, as well as an online survey of around 1,000 other teachers. The researchers asked primary teachers whether they were confident in teaching science; a total of $85 \%$ agreed that they were, including $32 \%$ who strongly agreed.

Here we present findings from a series of interviews with primary teachers, conducted at around the same time as the data collection for Leonardi's report, which complement its results and add additional qualitative detail about participants' levels of confidence in teaching science.

\section{Methodology}

Data collection for our study took place in June 2017 and consisted of a survey followed by a semi-structured telephone interview. We interviewed 14 teachers from mainstream primaries, two from independent primary schools and four from secondary schools; this paper focuses 
on the primary teacher group only. All interviewees were preparing to bring a class to visit the Lancashire Science Festival, a free event run by the University of Central Lancashire in Preston, UK, indicating that their schools placed sufficient value on science learning to spend a day out of the classroom devoted to it. Interview data was analysed using an inductive thematic process.

\section{Results and discussion}

Of our 16 primary interviewees, four expressed unqualified confidence in their science teaching ability and one explicitly stated that they lacked confidence. When we look at the characteristics of those that were fully confident, they marry up well with Leonardi's findings; the Wellcome Trust report found several characteristics that influence confidence in teaching science, including holding a science A level, being the school's science lead, and being male. Of our four fully-confident participants, three had more than one of these characteristics, while the fourth described a strong family background in science.

Where our report can add nuance to the findings is in the responses of the other 11 respondents, who described their science teaching confidence in conditional terms; as something not absolute, but dependent upon their actions or attitudes.

One common theme was that of 'doing my homework': the feeling that success in teaching science was down to deliberate preparation, that the wherewithal to make science a success still needed to be acquired. We asked the interviewees whether they felt confident in discussing science with their pupils; responses included:

"Pretty much. I do generally gen up again before I go in. I do like to go and have a little read again, so not quite as confident in that sense."

"I do my homework before we do it - I think so, fairly confident."

"I always do my research beforehand. I've taught the same class for a number of years now but if there's anything new I would have to do research first."

Whether or not such 'homework' is a feature of teaching other subjects at primary level is beyond the scope of our study. However, if it is the case that there is more preparation involved in teaching science than for other subjects, then one can see that this might be a negative influence on how much science is taught.

In one or two cases, scientific discussions seemed to be a potential source of stress; one interviewee, for example, told us that while she was comfortable talking to her pupils about

Corresponding Author: Cherry Canovan, ccanovan@uclan.ac.uk

Citation: Canovan, C. (2021). Doing my homework: sources of confidence for primary educators teaching science. Academia Letters, Article 675. https ://doi.org/10.20935/AL675. 
science, "if you asked me to speak to a real scientist I would probably be horrified!" Another said that she had to feel confidence in discussing science with the children,

“...because they would eat you alive if you didn't! They've got a very good sense of smelling fear, especially in Key Stage 2 children. They know when you don't know what you're talking about."

These teachers said that they were confident in discussing science with their pupils, but implicit in their phraseology is a narrative of concern - is their understanding of science really good enough? Again, it would be interesting to investigate whether such concerns extend to other subjects - would teachers be 'horrified' to speak to a real historian, or be 'eaten alive' if they didn't understand music? If such negative affect is particular to science then again, this might adversely influence how the subject is taught.

Some teachers who felt confident in speaking about science due to being well-prepared still highlighted difficulties with practical work and experiments; in this area, a number of teachers felt that external help was needed for them to make the most of the activity. One rather plaintively felt that her science teaching would be improved by "Resources [to help with] knowing why something has or is happening." Others felt that help was needed with the practical aspects of experiment delivery; one said that "[You] need a lot of in-house training [to do] good fun practical activities," while another had concerns about safety:

"I went on a course... the thing about science in primary school [is that I'm] not sure how much we are allowed to do in practical terms - we don't have a fume cupboard. [The tutor] lit tealights and said it was perfectly safe, but before I heard her say that I wouldn't do it."

These comments suggest that Continuing Professional Development (CPD) programmes in the practical aspects of teaching science might help to improve teachers' confidence. However making such programmes effective in practice is not without difficulties; for example, Abrahams (Abrahams et al., 2014) found that one such initiative "was effective in getting teachers to reflect on... ideas... [but] was much less effective in bringing about changes in actual teaching practice".

Finally, there were a group of teachers who expressed confidence in teaching science, not because they felt they had a complete grasp of the subject, but rather because they had accepted the limits of their knowledge. This group felt happy to express these limitations to their pupils:

Academia Letters, April 2021

C 2021 by the author - Open Access — Distributed under CC BY 4.0

Corresponding Author: Cherry Canovan, ccanovan@uclan.ac.uk

Citation: Canovan, C. (2021). Doing my homework: sources of confidence for primary educators teaching science. Academia Letters, Article 675. https ://doi .org/10.20935/AL675. 
“There are still some things I don't understand, and we can go and research why this happens. I have to say to the children 'I'm not really sure why this happens, let's find out'. I don't claim to be an expert."

and, in fact, felt able to use them as a teaching aid:

“...if there's anything I don't understand I say, 'you need to go and find out, and you need to teach me it'. Some kids will take that up."

This was felt to be a skill that was developed over time:

"My confidence has grown. I am not scared to tell children I don't know and will find out for them."

It is interesting to note that Wellcome found that length of time in the teaching profession was correlated with increased science teaching confidence. These comments suggest that it is possible that a developed willingness to be open about knowledge gaps is one factor in this. Again, one might suggest that this is an area where CPD - of a particular type - might help. A 2015 CBI report (CBI, 2015) found that CPD was "intrinsically linked" to the issue of confidence with science among primary teachers: "When we asked teachers what would help them to build their confidence in teaching science, $62 \%$ called for more professional development focused on science." Given the above findings, one might suggest that CPD that focused on science as a process of investigation rather than on factual information might be more successful in building confidence.

\section{Conclusions}

Our study suggests that the figure of $85 \%$ of teachers expressing confidence in teaching science recorded by the Wellcome Trust is underpinned by a patchwork of sentiments and dispositions. For some, this confidence is supported by their determination to 'do their homework' before teaching; others feel confident in areas such as discussing science with pupils, but lack such certainty in areas such as practical work. While some with more background in science for example, post-compulsory qualifications - feel unconditionally confident in teaching the subject, others have reached a place of confidence through an acceptance of not knowing, of science as a process of discovery. Whether CPD that places a greater emphasis on primary science as exploratory rather than factual could improve primary teachers' comfort with science is a question that merits further study.

Corresponding Author: Cherry Canovan, ccanovan@uclan.ac.uk

Citation: Canovan, C. (2021). Doing my homework: sources of confidence for primary educators teaching science. Academia Letters, Article 675. https ://doi .org/10.20935/AL675. 


\section{Bibliography}

Abrahams, I., Reiss, M. J., \& Sharpe, R. (2014). The impact of the 'Getting Practical: Improving Practical Work in Science' continuing professional development programme on teachers' ideas and practice in science practical work. Research in Science \& Technological Education, 32(3), 263-280. https://doi.org/10.1080/02635143.2014.931841

CBI. (2015). Tomorrow's world: Inspiring primary scientists. https://www.stem.org.uk/ resources/elibrary/resource/35987/tomorrows-world-inspiring-primary-scientists

Harlen, W., \& Holroyd, C. (1997). Primary teachers' understanding of concepts of science: impact on confidence and teaching. International Journal of Science Education, 19(1), 93-105. https://doi.org/10.1080/0950069970190107

Khwaja, C. (2002). The Role of Subject Knowledge in the Effective Teaching of Primary Science. https://www.researchgate.net/publication/26598047_The_Role_of_Subject_Knowledge_ in_the_Effective_Teaching_of_Primary_Science

Murphy, C., Neil, P., \& Beggs, J. (2007). Primary science teacher confidence revisited: Ten years on. Educational Research, 49(4), 415-430. https://doi.org/10.1080/00131880701717289

Ofsted. (2013). Maintaining Curiosity: A survey into science education in schools. https:// www.gov.uk/government/publications/maintaining-curiosity-a-survey-into-science-educationin-schools

Wellcome. (2014). Primary Science: Is It Missing Out? https://wellcome.org/sites/default/ files/primary-science-is-it-missing-out-wellcome-sep14.pdf

Wellcome Trust. (2017). "State of the nation" report of the UK primary science education. www.cfe.org.uk 